Kinerja Guru Bersertifikasi ... (Sudarno Shobron dan Suyanto)

\title{
KINERJA GURU BERSERTIFIKASI DALAM MENINGKATKAN MANAJEMEN MUTU PENDIDIKAN DI MADRASAH IBTIDAIYAH MUHAMMADIYAH SUDUNG KE- DUNGTUBAN BLORA TAHUN 2015
}

\author{
Sudarno Shobron \\ Universitas Muhammadiyah Surakarta (UMS) \\ Jl. A. Yani Pabelan Tromol Pos I Surakarta 57102 \\ E-Mail: ss175@ums.ac.id
}

\section{Suyanto}

Desa Wado RT.05/RW.06 Kec. Kedungtuban Kabupatern Blora Jawa Tengah E-Mail: suyantohs@yahoo.com

\begin{abstract}
The performance of school teachers be one of the important factors in improving the schools quality. Certified teachers in Ibtidaiyah Elementary School of Muhammadiyah Sudung Blora include planning and implementation of education quality development has been carried out effectively and efficiently. It is characterized by the realization of the development of the implementation of learning and learning outcomes in accordance with the vision and mission of the madrassa. support Factor in improving education quality management are 1) Availability of adequate learning media and support ongoing learning activities; 2) The interest and enthusiasm of students is increasing in participating in learning activities; 3) Preparation of teachers in teaching is increasing; 4) The climate in the classroom learning environment more conducive; 5) There is full support of the school community, society, and government; 6) Supplied facilities for picking up the students to and from school by teachers. Inhibiting factors in improving the quality of education management in MI Muhammadiyah Sudung are 1) Lack of facilities to support the library and its contents; 2) Many teachers who are still miss match (not in accordance with the latest science education qualifications); 3) Lack of infrastructure eg. UKS room, and laboratory, so it is still a hard time in learning practices.
\end{abstract}

Keywords: teacher performance; certification; management quality; education.

\begin{abstract}
Abstrak: Kinerja guru disekolah menjadi salah satu faktor penting dalam meningkatkan mutu sekolah. Guru bersertifikasi di Madrasah Ibtidaiyah Muhammadiyah Sudung Kabupaten Blora meliputi perencanaan dan pelaksanaan pengembangan mutu pendidikan telah dilakukan secara efektif dan efisien. Hal ini ditandai dengan terwujudnya pengembangan pelaksanaan pembelajaran dan hasil pembelajaran sesuai dengan visi dan misi madrasah. Fakor pendukung dalam meningkatkan manajemen mutu pendidikan ialah 1) Tersedianya media pembelajaran yang memadai dan menunjang berlangsungnya kegiatan belajar mengajar; 2) Minat dan semangat siswa semakin meningkat dalam mengikuti kegiatan pembelajaran; 3) Persiapan guru dalam pembelajaran semakin meningkat; 4) Iklim lingkungan belajar dalam kelas yang semakin kondusif; 5) Adanya dukungan penuh dengan warga sekolah, masyarakat, dan pemerintah; 6) Disediakan fasilitas antar jemput siswa saat berangkat dan pulang sekolah oleh guru-guru. Faktor penghambat dalam meningkatkan manajemen mutu pendidikan di MI Muhammadiyah Sudung ialah 1) Kurangnya fasilitas pendukung perpustakaan beserta isinya; 2) Tenaga pengajar masih banyak yang miss match (tidak sesuai dengan kualifikasi ilmu pendidikan terakhir); 3) Kurangnya sarana prasarana misalnya ruangan UKS, dan laborato-
\end{abstract}


rium, sehingga masih kesulitan saat praktek pembelajaran.

Kata Kunci: kinerja guru; sertifikasi; manajemen mutu; pendidikan.

\section{PENDAHULUAN}

Kualitas pendidikan merupakan kebutuhan sekaligus tuntutan yang hakiki untuk mencapai tujuan pendidikan. Tanpa pendidikan yang berbobot dan berkualitas, upaya mencerdaskan bangsa dan mengembangkan sumber daya manusia seutuhnya sulit mencapai sasaran. Kualitas pendidikan dapat dicapai dengan menciptakan iklim sejuk pembelajaran yang menyenangkan sehingga mampu memotivasi dan mendorong semangat belajar siswa, serta mampu memberdayakan kemampuan peserta didik.

Setelah lahirnya Undang-Undang Guru dan Dosen melalui UU Nomor 14 Tahun 2005, secara legal formal guru dan dosen menjadi profesi yang sangat diharapkan dalam meningkatkan kualitas pendidikan di Indonesia. Kualitas pendidikan tentu bermuara pada kualifikasi sumber daya manusia, baik secara fisikal (kesehatan), psikologikal (mental), intelektual, afektif (sikap dan etik), termasuk spiritual (nilainilai religius).

Berkaitan dengan masalah peningkatan mutu pendidikan tidak bisa dilepaskan dari pengaruh kinerja guru di sekolah. Pada saat ini guru professional yakni yang telah memiliki sertifikat pendidik memiliki peran penting terhadap manajemen mutu pendidikan di sekolah. Kinerja guru sertił fikasi secara umum di Madrasah Ibtidaiyah Muhammadiyah Sudung Kedungtuban Blora selama ini tentu mempengaruhi pei laksanaan tugasnya. Oleh karena itulah peneliti berusaha menganalisis kinerja guru sertifikasi kaitannya dengan peningkatan manajemen mutu pendidikan di Madrasah Ibtidaiyah (MI) Muhammadiyah Sudung Kedungtuban Blora.

Rumusan masalah penelitian ini: 1) Bagaimanakah kinerja guru bersertifikasi di Madrasah Ibtidaiyah (MI) Muhammadiyah Sudung Kedungtuban Blora Tahun
2015?; 2) Apa hambatan dan dukungan dalam meningkatkan manajemen mutu pendidikan di Madrasah Ibtidaiyah (MI) Muhammadiyah Sudung Kedungtuban Blora Tahun 2015?

Penelitian ini dilakukan dengan tujuan 1) Untuk mengetahui kinerja guru bersertifikasi di Madrasah Ibtidaiyah (MI) Muhammadiyah Sudung Kedungtuban Blora; 2) Untuk mengetahui hambatan kinerja guru dan upaya-upaya yang digunakan dalam meningkatkan manajemen mutu pendidikan di Madrasah Ibtidaiyah (MI) Muhammadiyah Sudung Kedungtuban Blora.

Manfaat penelitian : 1) Manfaat akademis dari penelitian ini yakni dapat menyumbangkan khazanah ilmiah bagi pengembang bidang manajemen pendidikan Islam; 2) Manfaat secara praktis Memberikan masukan bagi Madrasah Ibtidaiyah (MI) Muhammadiyah Sudung Kedungtuban untuk meningkatkan kualitas pendidikan dan mengetahui kinerja guru mampu meningkatkan mutu pendidikan. Pelaksanaan kinerja guru dalam upaya meningkatkan mutu pendidikan yang dilandasi beberapa pendekaran untuk meningkatkan mutu pendidikan melalui peningkatan kinerja sumber daya guru.

Kinerja atau prestasi kerja (performance) diartikan sebagai ungkapan kemampuan yang didasari oleh pengetahuan, sikap, ketrampilan dan motivasi dalam menghasilkan sesuatu. Simamora menyatakan bahwa prestasi kerja (performance) diartikan sebagai suatu pencapaian persyaratan pekerjaan tertentu yang akhirnya secara langsung dapat tercermin dari output yang dihasilkan baik kuantitas maupun kualitasnya. ${ }^{1}$ Prestasi kerja merupakan sejumlah output dari outcomes yang dihasilkan suatu kelompok atau organisasi tertentu baik yang berbentuk

1 Bilson Simamora, Analisis Multivariat Pemasaran, (Jakarta: Gramedia Pustaka Utama, 2005), hlm. 423 
materi (kuantitatif) maupun yang berbentuk nonmateri (kualitatif). Pada organisasi atau unit kerja di mana input dapat teridentifikasi secara individu dalam bentuk kuantitas misalnya pabrik jamu, indikator kinerja pekerjaannya dapat diukur dengan mudah, yaitu banyaknya output yang dicapai dalam kurun waktu tertentu. Namun untuk unit kerja kelompok atau tim, kinerja tersebut agak sulit, dalam hubungan ini kinerja dapat dilihat dari indiktor-indikator sebagai berikut : 1) keputusan terhadap segala aturan yang telah ditetapkan organisasi, 2) Dapat melaksanakan pekerjaan atau tugasnya tanpa kesalahan (atau dengan tingkat kesalahan yang paling rendah), 3) Ketepatan dalam menjalankan tugas. ${ }^{2}$

Manajemen kinerja (performance management) adalah satu upaya untuk memperoleh hasil terbaik dari organisasi, kelompok dan individu-individu melalui pemahaman dan penjelasan kinerja dalam suatu kerangka kerja atas tujuan-tujuan terencana, standar dan persyaratan-persyaratan atribut atau kompetensi yang disetujui bersama. ${ }^{3}$ Manajemen kinerja bersifat menyeluruh dan menjamah semua elemen, unsur atau input yang harus didaya gunakan oleh organisasi untuk meningkatkan kinerja organisasi. Sistem manajemen kinerja berusaha mengidentifikasikan, mendorong, mengukur, mengevaluasi, meningkatkan dan memberi penghargaan terhadap kinerja karyawan.

Undang-Undang Nomor 14 tahun 2005 tentang Guru dan Dosen pasal 1 butir 11 dikemukakan bahwa sertifikasi adalah proses pemberian sertifikat pendidik untuk guru dan dosen. Sedangkan pada butir 12 dikatakan bahwa sertifikat pendidik adalah bukti formal sebagai pengakuan yang diberikan kepada guru dan dosen sebagai tenaga profesional. ${ }^{4}$ Sertifikasi guru dapat diarti-

2 Bilson Simamora, Analisis Multivariat ... hlm. 26

3 Surya Dharma, Manajemen Kinerja: Falsafah, Teori, dan Penerapannya, (Yogyakarta: Pustaka Pelajar, 2010), hlm. 25

4 Undang-undang No. 20 tahun 2003 tentang Sistem Pendidikan Nasional (Jakarta : Media Pustaka Mandiri, 2006), hlm.4. kan sebagai proses pemberian pengakuan bahwa seseorang telah memiliki kompetensi untuk melaksanakan pelayanan pendidikan pada satuan pendidikan tertentu, setelah lulus uji kompetensi yang diselenggarakan oleh lembaga sertifikasi. Guru sertifikasi dengan kata lain dapat dikatakan sebagai guru profesional.

Guru profesional harus memenuhi prinsip-prinsip:

1. memiliki kualifikasi akademik dan latar belakang pendidikan sesuai dengan bidang tugas;

2. memiliki kompetensi yang diperlukan sesuai dengan bidang tugas;

3. memiliki tanggung jawab atas pelaksanaan tugas keprofesionalan;

4. memperoleh penghasilan yang ditentukan sesuai dengan prestasi kerja;

5. memiliki kesempatan untuk mengembangkan keprofesionalan secara berkelanjutan dengan belajar sepanjang hayat;

6. memiliki jaminan perlindungan hukum dalam melaksanakan tugas keprofesionalan; dan

7. memiliki organisasi profesi yang mempunyai kewenangan mengatur hal-hal yang berkaitan dengan tugas keprofesionalan guru. ${ }^{5}$

Guru yang telah bersertifikat mendapatkan tambahan tunjangan keuangan tiap bulannya, sehingga diharapkan dapat memenuhi kebutuhan hidupnya secara layak. Kalau kesejahteraan guru sudah tercukupi, maka secara normatif guru akan lebih fokus dalam menjalankan tugas-tugas dengan baik di sekolah, sejak mempersiapkan materi yang akan diajarkan kepada siswa, strategi pembelajaran yang akan diterapkan dan sistem evaluasi yang telah direncanakan termenej dengan baik. Dampak dari semua ini mestinya akan meningkatkan kualitas lulusan, sehingga Sumber Daya Manusia yang dihasilkan lebih optimal.

5 Undang-undang No 14 Tahun 2005 tentang Guru dan Dosen Bab III pasal 7 ayat 1 


\section{METODE PENELITIAN}

Paradigma dalam penelitian ini yakni penelitian kualitatif, yang hasilnya lebih menekankan makna daripada generalisasi. ${ }^{6}$ Melalui penelitian kualitatif ini diharapkan memperoleh pemahaman dan penafsiran yang mendalam mengenai kinerja guru bersertifikasi kaitannya dengan peningkatan manajemen Madrasah Ibtidaiyah (MI) Muhammadiyah Sudung Kedungtuban Blora.

Ruang lingkup penelitian ini merupakan penelitian pendidikan karena akan mengungkap tentang kinerja guru dalam sebuah lembaga pendidikan dari sisi sertifikasi dan non sertifikasi. Penelitian ini juga merupakan penelitian lapangan (field research) dengan tipe penelitian deskriptif. Sumber data dalam penelitian ini yakni kepala madrasah, guru-guru, dan dokumen-dokumen administrasi sekolah dan administrasi pembelajaran guru. Obyek penelitiannya adalah MI Muhammadiyah Sudung Kedungtuban Blora. Sedangkan subyek penelitian yaitu guru sertifikasi MI Muhammadiyah Sudung Kedungtuban Blora. Termasuk dalam subyek penelitian disini berupa dokumen-dokumen pendukung di MI Muhammadiyah Sudung Kedungtuban Blora.

Pengumpulan data penelitian ini menggunakan : 1) Wawancara. Data yang diambil dari metode wawancara ini adalah data mengenai bagaimana guru sertifikasi MI Muhammadiyah Sudung Kedungtuban Blora melakukan pengembangan manajemen mutu pendidikan berdasarkan nilainilai pendidikan disertai pertimbangan apa saja, dan bagaimana pelaksanaan dari penerapan pengembangan manajemen mutu pendidikan tersebut, serta data lain yang terkait; 2) Observasi. Metode observasi ini dilakukan untuk mendapatkan data tentang berbagai pelaksanaan pengembangan manajemen mutu pendidikan dan berbagai langkah atau kebijakan yang telah dilakukan oleh kepala sekolah dan Yayasan; 3) Dokumentasi. Teknik dokumentasi dalam

6 Sugiyono, Metode Penelitian AdMinistrasi, cet. 9 (Bandung: Alfabeta, 2002), hlm. 4 rangka mendapatkan data mengenai guru dan karyawan serta kepala sekolah, pelaksanaan administrasi pendidikan dan evaluasi, termasuk notulen, SK pembagian tugas, serta data lain yang relevan.

Analisis data dalam penelitian ini dilakukan berdasarkan model analisis interaktif sebagaimana dikembangkan oleh Matthew B. Miles yang terdiri dari 3 (tiga ) komponen analisis yang saling berinteraksi, yaitu reduksi data atau penyederhanaan data (data reduction), sajian data (data display), dan penarikan simpulan (data conclution: Drawing/ veryfying).?

\section{HASIL DAN PEMBAHASAN}

Pelaksanaan manajemen mutu pendidikan, pada awalnya yang dilakukan guru-guru bersertifikasi di MI Muhammadiyah Sudung secara aktif turut mempersiapkan perencanaan bersama kepala madrasah meliputi: ${ }^{8}$ 1) Memperhatikan berapa banyak waktu yang dapat digunakan dalam usaha peningkatan mutu, seperti efektifitas pelaksanaan pembelajaran, sehingga di batas waktu yang ada itu akan tersedia ruang waktu untuk melaksanakan aktifitas. Baik aktifitas kegiatan pendidikan atau aktifitas manajemen dan kepemimpinan dalam sekolah $^{9}$; 2) Tujuan, target atau sasaran yang hendak dicapai dalam kurun waktu yang tersedia. Misalnya, tujuan pembelajaran oleh guru dalam satu pertemuan per-jam pelajaran, dalam satu hari, satu pekan, satu bulan, per-semester dan per-tahun agar dapat dirumuskan cara mencapai tujuan tersebut melalui penguraian daftar kegiatan yang harus dilaksanakan (to do list); 3) Menguraikan kegiatan-kegiatan yang perlu dilakukan dalam mencapai tujuan dalam kurun waktu tertentu dilengkapi dengan

7 Mattew B.Miles, Qualitative and Analisis, (California : Sage Publication, 1994), hlm. 12.

8 Wawancara dengan Sardi, S.Ag Kepala MI Muhammadiyah Sudung, pada tanggal 4 Agustus 2015

9 Wawancara dengan Sardi, S.Ag Kepala MI Muhammadiyah Sudung, pada tanggal 4 Agustus 2015 
durasi pelaksanaan kegiatan tersebut; 4) Membuat evaluasi diri atas pelaksanaan kegiatan yang telah menggunakan waktu untuk mencapai tujuan yang telah direncanakan sebelumnya. Hal ini untuk mengetahui pencapaian tujuan, kendala yang ada, serta keuntungan dari pemanfaatan waktu tersebut; 5) Membuat sebuah catatan revisi atau perbaikan yang perlu dilakukan di masa datang setelah mengevaluasi pemanfaatan waktu terlaksana untuk dimasukkan sebagai bahan perbaikan pada rencana waktu yang baru.

Guru bersertifikasi memiliki kinerja positif peranannya dalam penyusunan visi dan misi madrasah. Hal ini terlihat dari indikator Keunggulan pada Visi Madrasah sebagai mana dalam tabel berikut ini:

Tabel 1. Pengembangan Mutu Terkait Visi MI Muhammadiyah Sudung

\begin{tabular}{|c|c|c|c|}
\hline No & Indikator Visi & $\begin{array}{c}\text { Bentuk Pengembangan } \\
\text { Tahun } 2015 \\
\end{array}$ & $\begin{array}{c}\text { Bentuk Pengembangan } \\
\text { Tahun } 2014 \\
\end{array}$ \\
\hline \multirow[t]{4}{*}{1.} & \multirow[t]{4}{*}{ Sosialisasi } & $\begin{array}{l}\text { Memampang Visi dan } \\
\text { Misi di papan dinding } \\
\text { sekolah serta di ke- } \\
\text { las-kelas. }\end{array}$ & \multirow{2}{*}{$\begin{array}{l}\text { Visi dan Misi belum } \\
\text { dipampang di dinding } \\
\text { dan ruang kelas. } \\
>\quad \text { Tidak disosialisasi mas } \\
\text { alah Visi dan Misi }\end{array}$} \\
\hline & & $>$ Memberikan sosialisa- & \\
\hline & & $\begin{array}{l}\text { madrasah. } \\
\text { mat momite }\end{array}$ & \multirow{2}{*}{$\begin{array}{l}\text { Siswa tidak wajib } \\
\text { menghafalkan } \\
\text { masrasah }\end{array}$} \\
\hline & & $\begin{array}{l}>\text { Siswa menghafalkan } \\
\text { misi madrasah }{ }^{1}\end{array}$ & \\
\hline \multirow[t]{4}{*}{2} & $\begin{array}{l}\text { Unggul dalam } \\
\text { lomba Akademik. }\end{array}$ & $\begin{array}{l}\text { Mengikut sertakan lomba } \\
\text { yang diselenggrakan: }\end{array}$ & \multirow{4}{*}{$\begin{array}{l}\text { Kurang memperhati- } \\
\text { kan keikutsertaan lom- } \\
\text { ba-lomba pekan kreatif- } \\
\text { itas siswa. }\end{array}$} \\
\hline & & $\begin{array}{l}\text { Departemen Pendi- } \\
\text { dikan Nasional tingkat } \\
\text { UPTD TK/SD Keca- } \\
\text { matan. }\end{array}$ & \\
\hline & & $\begin{array}{l}\text { Departemen Pendi- } \\
\text { dikan nasional tingkat } \\
\text { Kabupaten belum men- } \\
\text { dapatkan juara hanya } \\
\text { bisa berpartisipasi saja. }\end{array}$ & \\
\hline & & $\begin{array}{l}\text { Penjabaran poin b ten- } \\
\text { tang visi dapat dipenuhi } \\
\text { walaupun dari segi ha- } \\
\text { sil kurang memuaskan } \\
\text { akan tetapi dengan ikut } \\
\text { berpartisipasi seudah } \\
\text { merupakan usaha me- } \\
\text { menuhi penjabaran visi } \\
\text { madrasah tersebut. }\end{array}$ & \\
\hline
\end{tabular}




\begin{tabular}{|c|c|c|c|}
\hline No & Indikator Visi & $\begin{array}{c}\text { Bentuk Pengembangan } \\
\text { Tahun } 2015\end{array}$ & $\begin{array}{c}\text { Bentuk Pengembangan } \\
\text { Tahun } 2014\end{array}$ \\
\hline 3 & $\begin{array}{l}\text { Unggul dalam } \\
\text { Disiplin }\end{array}$ & $\begin{array}{l}\text { Dibuktikan masuk jam } 6 \text {. } \\
45 \text { WIB, dengan dimulai } \\
\text { tadarus bersama selama } \\
15 \text { menit dikoordinir oleh } \\
\text { guru bersertifikasi sampai } \\
\text { masuk jam } 07.00 \text { saat pem- } \\
\text { belajaran di mulai sampai } \\
\text { jam } 12.50 \text { wib, saat jam } \\
\text { pembelajaran berakhir. Ke- } \\
\text { mudian pada jam tertentu } \\
\text { menggunakan waktu sore } \\
\text { hari antara jam } 14.00 \text { wib, } \\
\text { sampai jam } 16.00 \text { wib, un- } \\
\text { tuk melaksanakan ekstra- } \\
\text { kurikuler meliputi TPA, } \\
\text { Drum Band, Pramuka dan } \\
\text { pembuatan anyaman bam- } \\
\text { bu. Untuk kelas VI di ada- } \\
\text { kan les selama satu minggu } \\
\text { penuh, apalagi sekarang } \\
\text { menjelang Ujian Sekolah } \\
\text { yang akan diselenggarakan } \\
\text { pada bulan-bulan menda- } \\
\text { tang. }\end{array}$ & $\begin{array}{l}>\text { Belum ada tadarus } \\
\text { Qur`an. } \\
>\text { Drum Band sudah ada } \\
\text { tapi belum dapat dio- } \\
\text { perasikan. } \\
>\text { Pramuka sudah ada } \\
\text { sejak tahun 2010, dia- } \\
\text { ktifkan melalui Guru } \\
\text { Tidak Tetap sampai } \\
\text { sekarang } \\
>\text { Belum ada kegiatan } \\
\text { anyam bambu } \\
>\text { Les pendalaman materi } \\
\text { sudah ada sejak UNAS } \\
\text { diterapkan. }\end{array}$ \\
\hline 4 & $\begin{array}{l}\text { Unggul dalam } \\
\text { Aktifitas Keaga- } \\
\text { maan. }\end{array}$ & $\begin{array}{l}\text { Pengembangan mulai den- } \\
\text { gan kegiatan lomba kali- } \\
\text { grafi, adzan, pidato tingkat } \\
\text { kecamatan. Untuk mengha- } \\
\text { dapi MTQ yang diselengga- } \\
\text { rakan oleh Dinas maupun } \\
\text { kemenag, setiap satu ming- } \\
\text { gu sekali guru agama mela- } \\
\text { kukan pelatihan pada anak } \\
\text { yang berbakat pada bidan- } \\
\text { gnya, sehingga penjaringan } \\
\text { anak berbakat sudah dimu- } \\
\text { lai sedini mungkin. }\end{array}$ & $\begin{array}{l}\text { Kegiatan jeagamaan sela- } \\
\text { lu dikembangkan, karena } \\
\text { ma-drasah ini berciri khas } \\
\text { agama, sehingga keung-gu- } \\
\text { lan bidang keagamaan sela- } \\
\text { lu diperhatikan dan diuta- } \\
\text { makan. }\end{array}$ \\
\hline
\end{tabular}




\begin{tabular}{|c|c|c|c|}
\hline No & Indikator Visi & $\begin{array}{c}\text { Bentuk Pengembangan } \\
\text { Tahun } 2015\end{array}$ & $\begin{array}{c}\text { Bentuk Pengembangan } \\
\text { Tahun } 2014\end{array}$ \\
\hline 5 & $\begin{array}{l}\text { Unggul dalam } \\
\text { Kepedulian Sosial } \\
\text { dan Budaya. }\end{array}$ & $\begin{array}{l}\text { Pengembangan mutu me- } \\
\text { lalui kegiatan bakti sosial, } \\
\text { siswa terlibat langsung } \\
\text { saat ada pelaksanaan za- } \\
\text { kat fitrah, qurban, program } \\
\text { tarawih setiap ramadhan } \\
\text { berbaur dengan masyara- } \\
\text { kat untuk melaksanakan } \\
\text { kegiatan pengajian dan ke- } \\
\text { agamaan dan bantuan bagi } \\
\text { rakyat miskin terutama } \\
\text { beasiswa bagi siswa yang } \\
\text { anaknya sekolah di MI } \\
\text { Muhammadiyah Sudung. }\end{array}$ & $\begin{array}{l}\text { Pengembangan kegiatan } \\
\text { keagamaan dan pelak-sa- } \\
\text { naan syariat agama Islam } \\
\text { tetap diperhatikan dan } \\
\text { dilaksanakan seperti: } \\
>\text { Zakat Fitrah } \\
>\text { Qurban }\end{array}$ \\
\hline
\end{tabular}

Beberapa indikator partisipasi aktif guru bersertifikasi dalam pengembangan tujuan MI Muhammadiyah Sudung sebagaimana tabel berikut:

Tabel 2. Pengembangan Mutu Melalui Tujuan

\begin{tabular}{|c|c|c|c|}
\hline No & Indikator & Bentuk Pengembangan & Keterangan \\
\hline 1 & $\begin{array}{l}\text { Pemanfaatan } \\
\text { Waktu }\end{array}$ & $\begin{array}{l}\text { Mentargetkan pencapaian tujuan } \\
\text { tepat waktu melalui koordisasi } \\
\text { semua komponen madrasah. }\end{array}$ & $\begin{array}{l}\text { Koordinasi sebatas diperlu- } \\
\text { kan, jika tidak ada penekanan } \\
\text { dari atasan, komponen seko- } \\
\text { lah mela-kukan kegiatan pem- } \\
\text { belajaran saja. }\end{array}$ \\
\hline \multirow[t]{3}{*}{2} & $\begin{array}{l}\text { Strategi Penca- } \\
\text { paian }\end{array}$ & $\begin{array}{l}\text { mencamtumkan cara-cara, } \\
\text { bagaimana mencapai tujuan } \\
\text { dengan keterangan yang jelas } \\
\text { dan dapat dilakukan. }\end{array}$ & \multirow{3}{*}{$\begin{array}{l}\text { Hampir strategi penerapan } \\
\text { hanya dilakukan kepala ma- } \\
\text { drasah saja, tidak diserahkan } \\
\text { dengan kom-ponen sekolah } \\
\text { termasuk guru dan karyawan. } \\
\text { Pada tahun sebelumnya ad- } \\
\text { ministrasi madrasah belum } \\
\text { dikerjakan secara maksimal. }\end{array}$} \\
\hline & & $\begin{array}{l}\text { Digambarkan dalam bentuk } \\
\text { peta, dimana cara-cara men- } \\
\text { capai tujuan itu menjadi ter- } \\
\text { lihat jelas arah dan posisinya, } \\
\text { serta berapa banyak jumlah } \\
\text { waktu yang digunakan untuk } \\
\text { mencapai tujuan kegiatan. }{ }^{3}\end{array}$ & \\
\hline & & $\begin{array}{l}\text { Alat ukur (instrumen) untuk } \\
\text { mengevaluasi keberhasilan } \\
\text { kegiatan dengan cara mem- } \\
\text { buat format penilaian untuk } \\
\text { mengukur tanda-tanda ke- } \\
\text { berhasilan, dimana tujuan } \\
\text { sudah bisa dipastikan terca- } \\
\text { pai hingga berapa persen dari } \\
\text { target tujuan yang ditentukan } \\
\text { sebelumnya. }\end{array}$ & \\
\hline
\end{tabular}


Pencapaian mutu siswa dalam manajemen peningkatan mutu pendidikan adalah mengacu pada kegiatan siswa seperti dalam tabel.

Tabel 3. Pengembangan Mutu Siswa

\begin{tabular}{|c|c|c|}
\hline No & Kondisi Awal & Bentuk Pengembangan \\
\hline 1 & $\begin{array}{l}\text { Pelaksanaan Les hanya dilaku- } \\
\text { kan } 1 \text { bulan sebelum ujian seko- } \\
\text { lah di mulai }\end{array}$ & $\begin{array}{l}\text { Pelaksanaan les bagi siswa kelas VI selama } \\
\text { satu semester penuh yakni awal semester } 2\end{array}$ \\
\hline 2 & $\begin{array}{l}\text { Banyak Kekosongan akibat guru } \\
\text { yang memiliki tugas ganda sep- } \\
\text { erti bendahara dan pengadminis- } \\
\text { trasian madrasah }\end{array}$ & $\begin{array}{l}\text { Pembelajaran di kelas tidak boleh kosong, } \\
\text { jika mengerjakan tugas harus di luar pembe- } \\
\text { lajaran siswa }\end{array}$ \\
\hline 3 & $\begin{array}{l}\text { Belum ada buku paket pembela- } \\
\text { jaran, siswa dan guru hanya men- } \\
\text { catat dan menghafal }\end{array}$ & $\begin{array}{l}\text { Pemenuhan sarana buku paket dalam pem- } \\
\text { belajaran siswa }\end{array}$ \\
\hline 4 & $\begin{array}{l}\text { Ada ekstrakurikuler, tapi tidak } \\
\text { terlaksana }\end{array}$ & $\begin{array}{l}\text { Pemenuhan waktu kosong berupa pelaksa- } \\
\text { naan efektifitas kegiatan ekstrakurikuler, }\end{array}$ \\
\hline 5 & $\begin{array}{l}\text { Siswa dibiarkan kosong dan guru } \\
\text { hanya meninggalkan kelas tanpa } \\
\text { ada tugas siswa }\end{array}$ & $\begin{array}{l}\text { Pengaktifan tugas berstruktural, bagi guru } \\
\text { yang tugas berdasarkan surat tugas untuk } \\
\text { melakukan dinas luar, jika perlu guru piket } \\
\text { menggantikan memberikan, mengawasi ser- } \\
\text { ta mengevaluasi siswa sesuai dengan bidang } \\
\text { ajar yang ditinggalkan guru tersebut. }{ }^{4}\end{array}$ \\
\hline 6 & $\begin{array}{l}\text { Siswa tidak pernah dibuat siswa } \\
\text { unggulan }\end{array}$ & $\begin{array}{l}\text { Dibentuknya siswa unggulan, siswa yang di } \\
\text { tes melalui evaluasi unggulan yang memili- } \\
\text { ki nilai di atas rata-rata di berikan materi les } \\
\text { yang tujuannya akan memberikan pengaruh } \\
\text { pada siswa yang lain saat melakukan pem- } \\
\text { belajaran di kelas. }\end{array}$ \\
\hline
\end{tabular}

Peningkatan mutu pendidikan melalui sumber daya manusia difokuskan pada peningkatan kompetensi pribadi dan keahlian atau profesionalisme, diantaranya :

1. Memberikan peluang pada guru untuk melanjutkan pendidikan.

2. Mengusahakan beasiswa bagi guru yang sedang melanjutkan pendidikan.

3. Mengikut sertakan guru dalam acara work shop, seminar atau penataran-penataran yang ada hubungannya dengan bidang keahlian yang dimiliki.

4. Memberikan kebijakan berupa kemudahan pinjaman di bank, untuk memenuhi kebutuhan hidup dan peningkatan kesejahteraan guru.

5. Memasukkan guru-guru dalam kepengurusan di tingkat kecamatan seperti

\section{dalam kegiatan KKG. 10}

Kurikulum yang diterapkan di MI Muhammadiyah Sudung adalah KTSP (Kurikulum Tingkat Satuan Pendidikan). Program-program pengembangan kurikulum mengacu pada kebutuhan regional dan nasional dengan cara penyempurnaan kurikulum serta peningkatan managemen sekolah, sebagaimana dalam tabel di bawah ini.

10 Wawancara dengan Sardi, S.Ag Kepala MI Muhammadiyah Sudung, pada tanggal 4 Agustus 2015 
Tabel 4. Pengembangan Mutu Kurikulum

\begin{tabular}{cll}
\hline No & \multicolumn{1}{c}{ Kondisi Awal } & \multicolumn{1}{c}{ Bentuk Pengembangan } \\
\hline 1 & Madrasah Ibtidaiyah Muhammadi- & Penyusunan KTSP melalui Tim Penyusu- \\
& yah Sudung hanya menerima paket & nan KTSP MI Muhammadiyah Sudung \\
dari Kementerian Agama kabupaten & yang telah dilaksanakan pada bulan Juli \\
& Blora yang berasal dari pusat Jakarta, & sampai Agustus tahun 2014, yang men- \\
& hal tersebut dilakukan karena meny- & gacu pada materi paket pusat dengan \\
& usun KTSP tidaklah mudah oleh kare- & pengembangan pada materi ajar serta \\
na itulah sikap MIM Sudung hanya & kondisi regional. Penambahan Materi \\
& melaksanakan serta mencari kekuran- & yang paling nampak adalah pelaksanaan \\
& gan-kekuranagn kemudian di sempur- & pendidikan bahasa Inggris, Mulok.
\end{tabular}
nakan bersama melalui penyusunan standar isi. ${ }^{5}$

2 Belum pernah ada studi banding ten- Pelaksanaan studi banding melalui matang pengembangan kurikulum KTSP drasah unggulan, baik negeri maupun swasta untuk penyusunan dan pengembangan bidang studi umum dan Keagamaan.

3. Pengorganisasian kurikulum yang di jilid sesuai dengan tahun ajaran belum dilakukan, termasuk penyusunan RPP guru.
Kurikulum mulai ada pengembangan yaitu menyusun masing-masing kuri- kulum sesuai dengan bidang studi dan kelas, yang dijilid sesuai dengan tahun pelajaran dan pengembangan yang dilakukan.
$>$ Penyusunan RPP dilakukan saat guru libur semester, kemudian diajukan saat masuk semester hari pertama dengan kebijakan waktu senggang satu minggu untuk diajukan kepada kepala sekolah untuk mendapatkan pengesahan,

4. Guru belum boleh mengajukan angga-

Masing-masing guru berhak mengajukan rencana pengembangan pembelajaran sesuai dengan materi yang diampunya sekaligus membuat proposal materi dan kegiatan beserta anggaran dalam rangkan pengembangan kurikulum yang berkelanjutan, dan dilaporkan selama kegiatan sudah selesai dan mendapatkan hasil. ${ }^{6}$

Beberapa metode dan strategi mengajar yang dipergunakan oleh guru-guru di MI Muhammadiyah Sudung ialah Model pembelajaran kooperatif. Adapun tipe yang di- gunakan ialah STAD, Make a Match, Playing Card, Role play, Demonstrasi. Dari beberapa tipe tersebut menunjukkan guru memiliki penguasaan strategi mengajar yang baik. 
Hal ini ditunjang dengan penggunaan LCD Proyektor dalam mengajar sehingga menambah semangat para siswa untuk mengikuti proses pembelajaran.

Adapun Materi pembelajaran yang disampaikan kepada peserta didik dikuasai oleh guru-guru di MI Muhammadiyah Sudung. Hal ini dibuktikan dengan proses pembelajaran yang berjalan dengan tertib dan lancar. Guru-guru bersertifikasi di MI Muhammadiyah Sudung telah memenuhi kualifikasi pendidikan S1 sesuai dengan materi yang diajarkan.

Pengelolaan kelas yang dikembangkan oleh guru bersertifikasi di MI Muhammadiyah Sudung meliputi administrasi, fisik dan non fisik. Administrasi kelas terpenuhi dengan baik karena guru kelas memiliki administrasi yakni mencapai prosentase 85\%. Adapun aspek fisik meliputi kelengkapan alat peraga pembelajaran. Meskipun belum mencapai $100 \%$ tetapi alat tersebut semakin menunjukkan grafik peningkatan. Aspek non fisik berkaitan dengan penguasaan guru ketika mengajar apabila ada anak yang tidak berkonsentrasi dalam belajar maka guru senantiasa memberikan arahan dan bimbingan secara lisan. Peringatan tersebut secara bertahap dilakukan sehingga siswa merasa adanya kasih saying dari seorang guru.

Guru di MI Muhammadiyah Sudung melakukan penilaian terhadap hasil belajar siswa. Penilaian tersebut meliputi ulangan harian, sumatif, sub sumatif. Selain itu juga diadakan penilaian praktis untuk mengukur kemampuan fisik siswa. Hasil penilaian tersebut dievaluasi untuk mendapatkan tindak lanjut, sampai pada akhir semester diberikan laporan hasil semester.

Faktor pendukung dan penghambat Manajemen Mutu Pendidikan di MI Muhammadiyah Sudung sangat mempengaruhi kinerja guru.

\section{a. Faktor pendudukung}

1) Tersedianya media pembelajaran yang memadai dan menunjang berlangsungnya kegiatan belajar men- gajar,

2) minat dan semangat siswa semakin meningkat dalam mengikuti kegiatan pembelajaran.

3) Persiapan guru dalam pembelajaran semakin meningkat

4) Iklim lingkungan belajar dalam kelas yang semakin kondusif

5) Adanya dukungan penuh dengan warga sekolah, masyarakat, dan pemerintah.

6) Disediakan fasilitas antar jemput siswa saat berangkat dan pulang sekolah oleh guru-guru

b. Faktor penghambat.

1) Kurangnya fasilitas pendukung perpustakaan beserta isinya.

2) Tenaga pengajar masih banyak yang miss match (tidak sesuai dengan kualifikasi ilmu pendidikan terakhir).

1) Kurangnya sarana prasarana misalnya ruangan UKS, dan laboratorium, sehingga masih kesulitan saat praktek pembelajaran.

\section{KESIMPULAN}

Berdasarkan hasil dan pembahasan tentang guru bersertifikat dalam meningkatkan mutu pendidikan, maka dapat ditarik kesimpulan:

1. Kinerja guru bersertifikasi di MI Muhammadiyah Sudung Kabupaten Blora meliputi aspek perencanaan dan aspek pelaksanaan pengembangan mutu pendidikan telah dilakukan secara efektif dan efisien.

2. Guru bersertifikasi telah mampu mengembangkan pelaksanaan pembelajaran dan hasil pembelajaran sesuai dengan visi dan misi madrasah.

3. Guru bersertifikasi memberikan dampak positif terhadap menajemen pengelolaan lembaga pendidikan. 
Kinerja Guru Bersertifikasi ... (Sudarno Shobron dan Suyanto)

\section{DAFTAR PUSTAKA}

Dharma, Surya. 2010. Manajemen Kinerja: Falsafah, Teori, dan Penerapannya. Yogyakarta: Pustaka Pelajar.

Hasibuan, Malayu S.P. 2006. Manajemen Dasar, pengertian dan masalah, Cet. ke-5. Jakarta: Bumi Aksara.

Miles, Mattew B. 1994. Qualitative and Analisis. California : Sage Publication.

Simamora, Bilson. 2005. Analisis Multivariat Pemasaran. Jakarta: Gramedia Pustaka Utama.

Sugiyono. 2002. Metode Penelitian AdMinistrasi, cet. 9. Bandung: Alfabeta.

Undang-undang No. 20 tahun 2003 tentang Sistem Pendidikan Nasional. 2006. Jakarta : Media Pustaka Mandiri.

Usman, Husaini. 2006. Manajemen, Praktik dan reset Pendidikan. Jakarta: Bumi Aksara. 